\title{
Assessment of runs of homozygosity islands and estimates of genomic inbreeding in Gyr (Bos indicus) dairy cattle
}

Elisa Peripolli ${ }^{1} \mathbb{B}$, Nedenia Bonvino Stafuzza ${ }^{2}$, Danísio Prado Munari ${ }^{2,3}$, André Luís Ferreira Lima ${ }^{4}$, Renato Irgang ${ }^{4}$, Marco Antonio Machado ${ }^{3,5}$, João Cláudio do Carmo Panetto ${ }^{5}$, Ricardo Vieira Ventura ${ }^{6,7,8}$, Fernando Baldi, ${ }^{1,3}$ and Marcos Vinícius Gualberto Barbosa da Silva ${ }^{3,5^{*}}$

\begin{abstract}
Background: Runs of homozygosity $(\mathrm{ROH})$ are continuous homozygous segments of the DNA sequence. They have been applied to quantify individual autozygosity and used as a potential inbreeding measure in livestock species. The aim of the present study was (i) to investigate genome-wide autozygosity to identify and characterize $\mathrm{ROH}$ patterns in Gyr dairy cattle genome; (ii) identify $\mathrm{ROH}$ islands for gene content and enrichment in segments shared by more than $50 \%$ of the samples, and (iii) compare estimates of molecular inbreeding calculated from $\mathrm{ROH}\left(\mathrm{F}_{\mathrm{ROH}}\right)$, genomic relationship matrix approach ( $\left.F_{G R M}\right)$ and based on the observed versus expected number of homozygous genotypes $\left(\mathrm{F}_{\mathrm{HOM}}\right)$, and from pedigree-based coefficient $\left(\mathrm{F}_{\mathrm{PED}}\right)$.

Results: $\mathrm{ROH}$ were identified in all animals, with an average number of $55.12 \pm 10.37$ segments and a mean length of $3.17 \mathrm{Mb}$. Short segments $\left(\mathrm{ROH}_{1-2} \mathrm{Mb}\right)$ were abundant through the genomes, which accounted for $60 \%$ of all segments identified, even though the proportion of the genome covered by them was relatively small. The findings obtained in this study suggest that on average $7.01 \%(175.28 \mathrm{Mb})$ of the genome of this population is autozygous. Overlapping $\mathrm{ROH}$ were evident across the genomes and 14 regions were identified with $\mathrm{ROH}$ frequencies exceeding $50 \%$ of the whole population. Genes associated with lactation (TRAPPC9), milk yield and composition (IRS2 and ANG), and heat adaptation (HSF1, HSPB1, and HSPE1), were identified. Inbreeding coefficients were estimated through the application of $F_{R O H}, F_{G R M}, F_{H O M}$, and $F_{P E D}$ approaches. $F_{P E D}$ estimates ranged from 0.00 to 0.327 and $F_{\text {ROH }}$ from 0.001 to 0.201. Low to moderate correlations were observed between $F_{P E D}-F_{R O H}$ and $F_{G R M}-F_{R O H}$, with values ranging from -0.11 to 0.51. Low to high correlations were observed between $F_{\text {ROH }}-F_{H O M}$ and moderate between $F_{P E D}-F_{H O M}$ and $F_{G R M}-F_{H O M}$. Correlations between $\mathrm{F}_{\mathrm{ROH}}$ from different lengths and $\mathrm{F}_{\mathrm{PED}}$ gradually increased with $\mathrm{ROH}$ length.

Conclusions: Genes inside ROH islands suggest a strong selection for dairy traits and enrichment for Gyr cattle environmental adaptation. Furthermore, low $\mathrm{F}_{\mathrm{PED}} \mathrm{F}_{\mathrm{ROH}}$ correlations for small segments indicate that $\mathrm{F}_{\mathrm{PED}}$ estimates are not the most suitable method to capture ancient inbreeding. The existence of a moderate correlation between larger $\mathrm{ROH}$ indicates that $\mathrm{F}_{\mathrm{ROH}}$ can be used as an alternative to inbreeding estimates in the absence of pedigree records.
\end{abstract}

Keywords: Bos indicus, Dairy traits, Inbreeding coefficients, $\mathrm{ROH}$ islands

\footnotetext{
* Correspondence: marcos.vb.silva@embrapa.br

${ }^{3}$ Conselho Nacional de Desenvolvimento Científico e Tecnológico (CNPQ), Lago Sul 71605-001, Brazil

${ }^{5}$ Embrapa Gado de Leite, Juiz de Fora 36038-330, Brazil

Full list of author information is available at the end of the article
}

(c) The Author(s). 2018 Open Access This article is distributed under the terms of the Creative Commons Attribution 4.0 International License (http://creativecommons.org/licenses/by/4.0/), which permits unrestricted use, distribution, and reproduction in any medium, provided you give appropriate credit to the original author(s) and the source, provide a link to the Creative Commons license, and indicate if changes were made. The Creative Commons Public Domain Dedication waiver (http://creativecommons.org/publicdomain/zero/1.0/) applies to the data made available in this article, unless otherwise stated. 


\section{Background}

Autozygosity occurs when chromosomal segments arising from a common ancestor are identical by descent (IBD) and inherited from both parents on to the offspring genome [1]. This pattern of inheritance gives rise to continuous IBD homozygous segments characterized as runs of homozygosity ( $\mathrm{ROH})$ [2], which can be a consequence of several population phenomena [3]. The development of high-density SNP arrays to scan the genome for $\mathrm{ROH}$ has been proposed as a useful method to distinguish non-autozygotic segments that are identical by state (IBS) from those autozygotic and IBD [4].

As the occurrence of $\mathrm{ROH}$ tend to be revealed in the genome, its identification and characterization can provide an insight into how population structure and demography have evolved over time [5-7]. $\mathrm{ROH}$ can disclose the genetic relationships among individuals, estimating with a high accuracy the autozygosity at the individual and population levels [8-11] and can elucidate about selection pressure events $[10,12,13]$. As the expected length of the autozygous segment follows an exponential distribution with mean equal to $1 / 2 g$ morgans, where $g$ is equal to the number of generations since the common ancestor, the number of generations from the selection events can be inferred from the length and frequency of $\mathrm{ROH}[4]$.

The autozygosity based on $\mathrm{ROH}$ can help to improve the understanding of genetic selection process of quantitative traits as the selection is one of the main forces that tend to print homozygous stretches on the genome [14]. According to Zhang et al. [13], $\mathrm{ROH}$ patterns are not randomly distributed across the genomes, and $\mathrm{ROH}$ islands are seen to be distributed and shared among individuals, which is likely the result of selection events. Therefore, $\mathrm{ROH}$ can be used to explore signatures of selection [12, 14], since genomic regions sharing $\mathrm{ROH}$ potentially contain alleles associated with genetic improvement in livestock [6] and are of interest for breeding programs [14]. $\mathrm{ROH}$ can also be an accurate estimator of inbreeding considering that high levels of inbreeding increase the frequency of homozygous alleles [10].

Studies have considered pedigree-based estimates of inbreeding $\left(\mathrm{F}_{\mathrm{PED}}\right)$ since Wright [15], although the availability of whole-genome marker panels has widespread the use of genomic information in animal breeding [16]. Pedigree-based relatedness is calculated from statistical expectations of the probable proportion of genomic identity by descent, while genotype-based estimates show the current relatedness among individuals [17]. Molecular approaches based on inbreeding coefficient estimates derived from $\mathrm{ROH}\left(\mathrm{F}_{\mathrm{ROH}}\right)$ and based on genomic relationship matrix $\left(\mathrm{F}_{\mathrm{GRM}}\right)$ [18] are meaningfulness to avoid drawbacks of using pedigrees to analyze inbreeding. $\mathrm{F}_{\mathrm{ROH}}$ are worth to estimate genome-wide autozygosity as it captures the influence of relatedness among founders. $\mathrm{F}_{\mathrm{ROH}}$ also takes into account the stochastic nature of recombination and mutations loads [19], and the potential bias resulting from selection [20] as well.

The first Gyr (Bos primigenius indicus) animals in Brazil had arrived in 1912, and most of the bulls were imported between 1914 and 1921, being then incorporated in crosses [21]. Those imported animals were first consumed for beef cattle purpose, and some breeders started to use them for milk production. Gyr animals have been intensely applied as the basis for crosses with taurine dairy breeds due to its rusticity and greater tolerance to the tropical environment [22]. The mating between imported animals invariably led to a steep increase in inbreeding rate in the population, resulting in genetic gains and fixation of favorable alleles. Over time, the deleterious effects associated with boosted homozygosity arising from inbreeding are predisposed to reduce the genetic gains, implicating in a clear loss of genetic variability (reviewed by Peripolli et al. [23]). Hence, the intense use of founders' animals to create the first Gyr dairy lines presumably triggered the autozygosity. This outcome is due in part to the inexistence of a breeding program at the time [24], the limited number of animals imported from India and the small number of proven sires mated to disseminate the breed [25]. Therefore, maintaining genetic variability in the Gyr cattle in Brazil is a demanding issue, since Brazil is recognized as a Gyr genetic supplier to some tropical countries that have deficiencies in milk production. Genome-wide autozygosity is an upcoming research area with a growing interest in characterizing and comprehending the mechanisms involved in it, so as to preserve a long-term viability and sustainability of Gyr breeding programs.

The aim of this work was to assess genome-wide autozygosity in Gyr cattle to identify and characterize $\mathrm{ROH}$ patterns, as well as to investigate $\mathrm{ROH}$ islands for dairy gene content in segments shared by more than $50 \%$ of the population. Further, we aimed to compare estimates of molecular inbreeding calculated from $\mathrm{F}_{\mathrm{ROH}}, \mathrm{F}_{\mathrm{GRM}}$ and based on the observed versus expected number of homozygous genotypes $\left(\mathrm{F}_{\mathrm{HOM}}\right)$ with those obtained from $\mathrm{F}_{\mathrm{PED}}$.

\section{Results}

\section{Genomic distribution of runs of homozygosity}

$\mathrm{ROH}$ were identified in all 2908 individuals, totaling 161,362 homozygous segments among overall samples. On an individual animal basis, the average number of $\mathrm{ROH}$ per animal was $55.12 \pm 10.37$, with values ranging from 17 to 121 . The mean $\mathrm{ROH}$ length was $3.17 \mathrm{Mb}$ and the longest segment was $108.97 \mathrm{Mb}$ in length (33,050 SNPs) found on BTA8. The number of $\mathrm{ROH}$ per chromosome was greater for BTA5 (10,670 segments) and tended to 
decrease with chromosome length. The major fraction of chromosome residing in $\mathrm{ROH}$ was found on BTA25 (11.98\% of chromosomal length in a ROH) (Fig. 1).

Descriptive statistic of $\mathrm{ROH}$ number and length by classes is given in Table 1. The total length of $\mathrm{ROH}$ for Gyr is composed mostly of a high number of shorter segments $\left(\mathrm{ROH}_{1-2} \mathrm{Mb}\right)$. These segments accounted for approximately $60 \%$ of all $\mathrm{ROH}$ detected, which contributed, however, for less than $25 \%$ of the cumulative $\mathrm{ROH}$ length. While shorter $\mathrm{ROH}$ were abundant throughout the genome, the proportion of the genome covered by them was relatively small. In contrast, larger $\mathrm{ROH}$ $\left(\mathrm{ROH}_{>16 \mathrm{Mb}}\right)$ were at least twenty-five fold less abundant than shorter $\mathrm{ROH}\left(\mathrm{ROH}_{1-2} \mathrm{Mb}\right)$ and still covered a higher proportion of the genome than small and medium $\mathrm{ROH}$.

The animal displaying the highest autozygosity exhibited a $\mathrm{ROH}$ genome coverage encompassing $730.21 \mathrm{Mb}$ of the total autosomal genome extension covered by markers (29.20\% of the cattle genome), with $71 \mathrm{ROH} \geq \mathrm{ROH}_{1-2 \mathrm{Mb}}$, and a mean $\mathrm{ROH}$ length of $10.28 \mathrm{Mb}$. The least inbred animal exhibited a $\mathrm{ROH}$ genome coverage encompassing $48.81 \mathrm{Mb}$ (1.95\% of the cattle genome), with $32 \mathrm{ROH} \geq \mathrm{ROH}_{1-2} \mathrm{Mb}$, and a mean $\mathrm{ROH}$ length of $1.52 \mathrm{Mb}$. Differences among animals regarding the number of $\mathrm{ROH}$ and the length of the genome covered by them were observed (Fig. 2). The sum of all $\mathrm{ROH}$ per animal allowed the estimation of the percentage of the genome that is autozygous and an average value of $7.01 \%$ (175.28 Mb) was observed.

\section{Gene characterization in $\mathrm{ROH}$ islands}

Overlapping $\mathrm{ROH}$ were evident across the genome, and their genomic distribution was non-uniform both in length and position across chromosomes. A total of 14 regions with outlying $\mathrm{ROH}$ frequencies on BTA2, BTA6, BTA10, BTA12, and BTA14 were identified (Additional file 1). Among the described $\mathrm{ROH}$ islands, the strongest pattern was observed on BTA2 $(78,394,916: 87,587,063 \mathrm{bp})$, with an overlapping $\mathrm{ROH}$ region present in $92 \%$ of the samples (Fig. 3). The majority of SNPs within $\mathrm{ROH}$ regions showed higher linkage disequilibrium (LD) levels than the estimates obtained for the entire chromosome (Additional file 2).

A relevant number of genes $(n=282)$ inside these $\mathrm{ROH}$ islands were observed (Additional file 1), in which several of them play important role in the mammary gland biology and have a prominent importance in milk, dairy traits, and heat adaptation. Gene ontology (GO) and pathway analysis (KEEG) were performed by DAVID tool $[26,27]$ to obtain a broad functional insight into the set of genes. An enrichment of genes involved in several GO terms (14 molecular functions, 23 biological processes, and seven cellular components) and KEGG pathways was observed (Additional file 3).

\section{Pedigree and genomic inbreeding}

Descriptive statistics for $F_{P E D}$ and $F_{R O H}$ coefficients are presented in Table 2. Among $\mathrm{F}_{\mathrm{ROH}}$ estimates, it can be observed an increase in variation with $\mathrm{ROH}$ length, being evidenced by the coefficient of variation (CV).

Low to moderate correlations were observed between $\mathrm{F}_{\mathrm{PED}}-\mathrm{F}_{\mathrm{ROH}}$ and it increased with $\mathrm{ROH}$ length (Fig. 4). Additionally, $\mathrm{F}_{\mathrm{PED}}$ slightly correlated with $\mathrm{F}_{\mathrm{GRM}}(0.23)$. The correlations between $\mathrm{F}_{\mathrm{GRM}}-\mathrm{F}_{\mathrm{ROH}}$ were higher than those between $\mathrm{F}_{\mathrm{PED}}-\mathrm{F}_{\mathrm{ROH}}$ for all $\mathrm{ROH}$ classes described. $\mathrm{F}_{\mathrm{HOM}}$ highly correlated with $\mathrm{F}_{\mathrm{ROH}}$ over than $4 \mathrm{Mb}, \mathrm{F}_{\mathrm{PED}}$, and $\mathrm{F}_{\mathrm{GRM}}$.

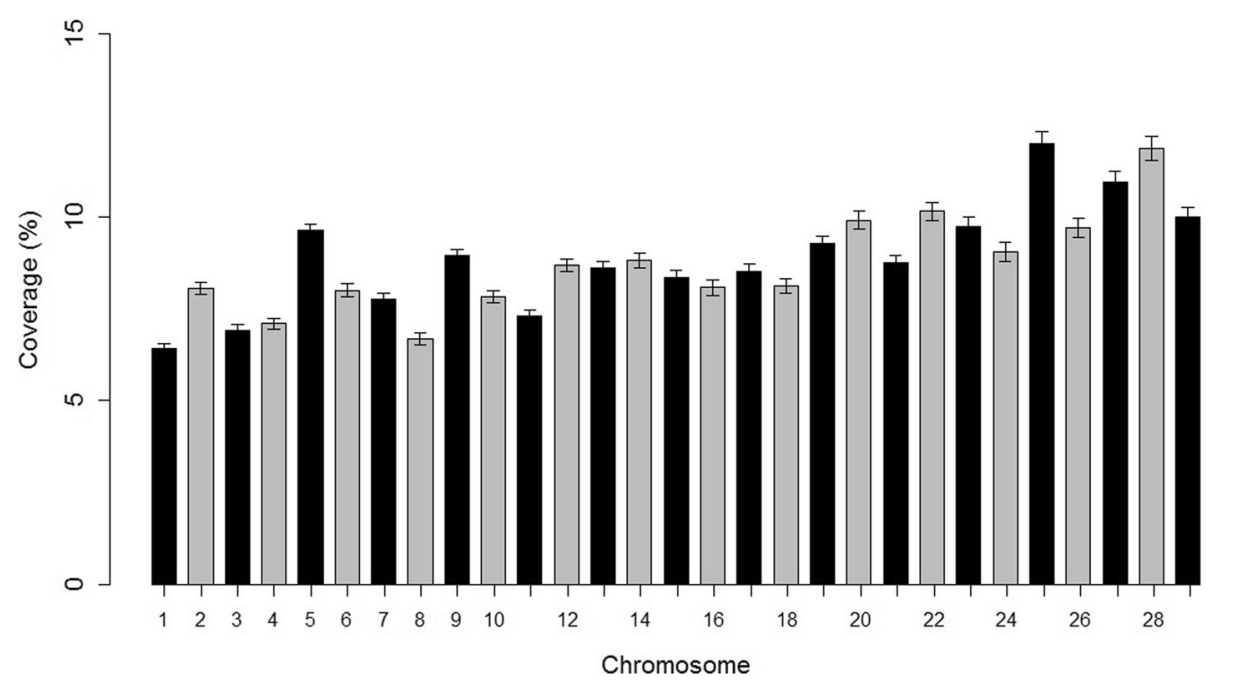

Fig. 1 Average percentage of chromosome coverage by runs of homozygosity of minimum length of $1 \mathrm{Mb}$. The error bars indicate the standard error 
Table 1 Descriptive statistics of runs of homozygosity number $(n \mathrm{ROH})$ and length (in $\mathrm{Mb}$ ) by $\mathrm{ROH}$ length class $\left(\mathrm{ROH}_{1}-2 \mathrm{MB}, \mathrm{ROH}_{2}-4 \mathrm{MB}\right.$, $\mathrm{ROH}_{4-8} \mathrm{MB}_{1}, \mathrm{ROH}_{8-16 \mathrm{MB}}$, and $\left.\mathrm{ROH}_{>16 \mathrm{Mb}}\right)$

\begin{tabular}{llllll}
\hline Class & $n \mathrm{ROH}$ & Percent & Mean length & Standard deviation & Genome coverage (\%) \\
\hline $\mathrm{ROH}_{1-2 \mathrm{Mb}}$ & 95,892 & 59.42 & 1.34 & 0.27 & 1.77 \\
$\mathrm{ROH}_{2-4} \mathrm{Mb}$ & 35,395 & 21.93 & 2.77 & 0.55 & 1.34 \\
$\mathrm{ROH}_{4-8 \mathrm{Mb}}$ & 17,843 & 11.05 & 5.54 & 1.12 & 1.36 \\
$\mathrm{ROH}_{8-16 \mathrm{Mb}}$ & 8518 & 5.27 & 10.98 & 2.17 & 1.46 \\
$\mathrm{ROH}_{>16 \mathrm{Mb}}$ & 3714 & 2.30 & 25.23 & 10.06 & 2.33 \\
\hline
\end{tabular}

The inbreeding evolution $\left(\mathrm{F}_{\mathrm{PED}}\right.$ and $\left.\mathrm{F}_{\mathrm{ROH}}\right)$ for animals born between 1980 and 2012 is shown in Fig. 5 and the genotyping sampling of animals per inbreeding coefficient in Table 2. The $F_{P E D}$ evolution showed a tendency to slightly increase over time (Fig. $5 \mathrm{a}$ ), while $\mathrm{F}_{\mathrm{ROH}}$ tended to decrease for segments higher than $4 \mathrm{Mb}$ (Fig. 5d-f).

\section{Discussion}

\section{Genomic runs of homozygosity patterns}

The greatest number of $\mathrm{ROH}$ per chromosome was described on BTA5, however, results in taurine breeds $[6,28,29]$ have evidenced the highest number of $\mathrm{ROH}$ on BTA1. The longest $\mathrm{ROH}$ was found on BTA8 with 108.97 $\mathrm{Mb}$ in length and similar results on BTA8 were reported by Kim et al. [10] in a contemporary Holstein cow (87.13 Mb) and Mastrangelo et al. [28] in Cinisara cattle breed (112.65 Mb).

The number of generations of inbreeding can be inferred from the extent of $\mathrm{ROH}$ since their extension is expected to correlate to ancient and recent inbreeding due to recombination events [1]. Therefore, due to recent inbreeding, $\mathrm{ROH}$ are expected to be longer since recombination did not have enough time to break up these IBD segments, while short $\mathrm{ROH}$ tend to reflect ancient inbreeding because the segments have been broken down by repeated meiosis [30]. The presence of segments larger than $10 \mathrm{Mb}$ is traceable to inbreeding from recent common ancestors that occurred only five generations ago [4], and 78\% of the animals comprised in this study presented at least one homozygous segment extending over $10 \mathrm{Mb}$. The reflection of a recent parental relatedness for animals with segments longer than $10 \mathrm{Mb}$ was confirmed when analyzing the pedigree back in only two generations, in which animals were seen to be inbred by their grand and great-grandparents.

The highest autozygosity value per animal was similar to those reported in the literature for dairy breeds. Purfield et al. [6] observed that dairy breeds were the most autozygous animals among several studied breeds, and had on average $700.3 \mathrm{Mb}$ of their genome classified as $\mathrm{ROH}$. Mastrangelo et al. [28] observed a close value for the Reggiana dairy breed $(725.2 \mathrm{Mb})$ and also did Szmatoła et al. [31] for Holstein cattle with $25 \%$ of their genome located in $\mathrm{ROH}$. It is noteworthy to highlight that Marras et al. [14] described that dairy breeds had a higher sum of all $\mathrm{ROH}$ than did beef breeds. The higher autozygosity observed in dairy breeds can be explained by the intense artificial selection and the repeatedly use of superior and proven sires for reproduction by artificial insemination [10]. In the Gyr cattle, it can be attributed to the rapid growth and dissemination of the breed over the last years, in which a small number of proven sires with high breeding value were frequently used [32].

Animals with the same length of the genome covered by $\mathrm{ROH}$ displayed a variable number of segments, which is likely a consequence of the distinct distances from the



Fig. 2 Number of $\mathrm{ROH}$ per individual and the length of the genome covered by $\mathrm{ROH}$ 


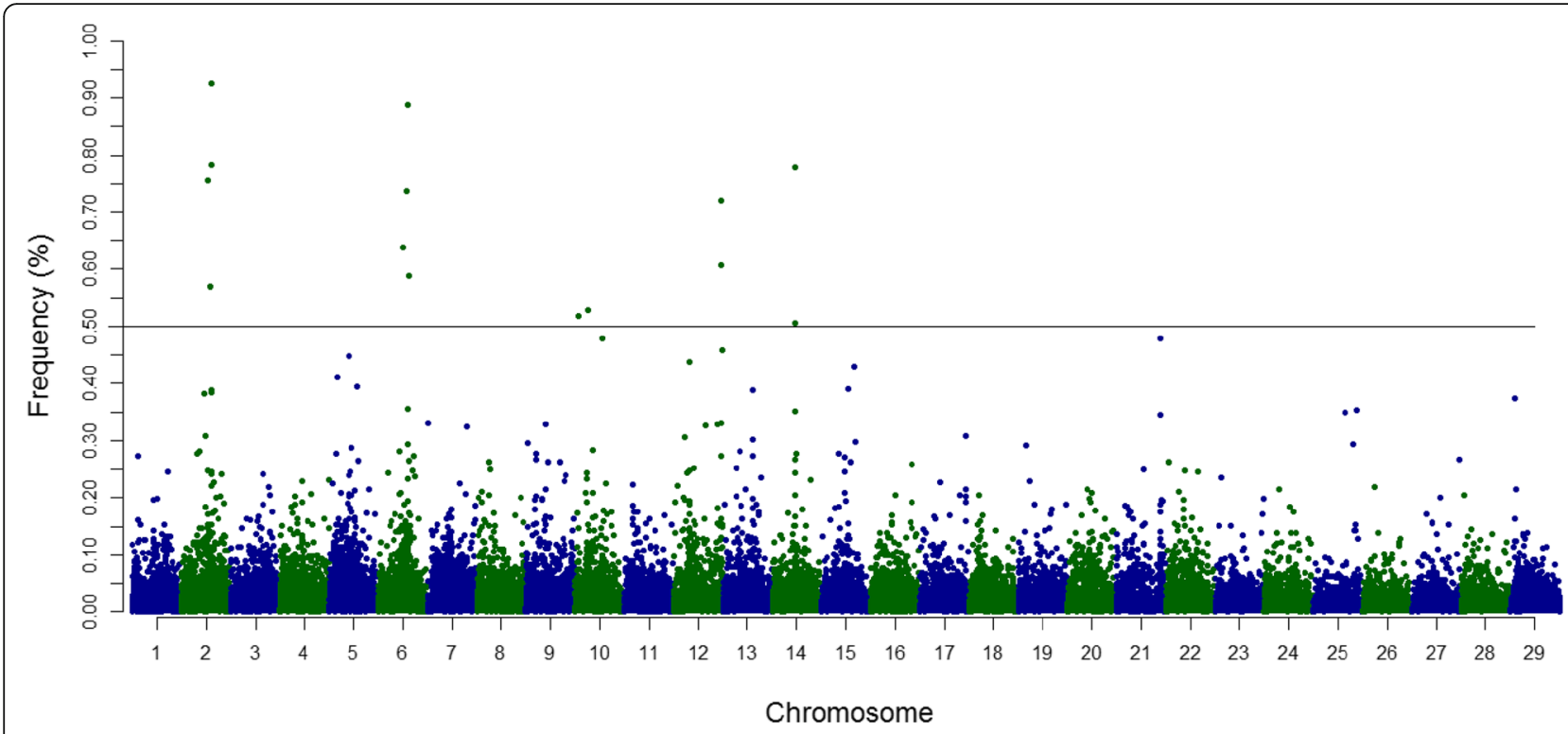

Fig. 3 Manhattan plot of the distribution of runs of homozygosity $(\mathrm{ROH})$ islands in the Gyr cattle genome. The X-axis represents the distribution of $\mathrm{ROH}$ across the genome, and the $\mathrm{Y}$-axis shows the frequency (\%) of overlapping $\mathrm{ROH}$ shared among samples

common ancestor, as also described by Mészáros et al. [33]. Overall, the autozygotic proportion of the genome found in this population was considered low given the Gyr dissemination historical process. A similar value was achieved by Marras et al. [14] (7\% for Marchigiana beef breed). Gyr cattle presented a lower genome average autozygosity compared to previous studies reported by Ferenčaković et al. [8] (9\% for Austrian dual purpose Simmental, Brown Swiss, and Tyrol Grey bulls) and Kim et al. [10] (10\% for Holstein cattle), and a higher autozygosity than results obtained by Zavarez et al. [11] (4.58\% for Nellore cattle).

\section{Runs of homozygosity islands and gene functional annotation}

The overlapping $\mathrm{ROH}$ regions observed across the genome suggest that these regions are likely a sign of $\mathrm{ROH}$ islands shared among animals [9]. $\mathrm{ROH}$ islands can be defined as genomic regions with reduced genetic diversity and, consequently, high homozygosity around the selected locus that might harbor targets of positive selection and are under strong selective pressure [34]. The strongest $\mathrm{ROH}$ island pattern on BTA2 $(78,394,916: 87,587,063$ bp) present in $92 \%$ of the samples showed an enrichment of genes involved with the immunity system. Similarly, Marras et al. [14] reported a $\mathrm{ROH}$ in $90 \%$ of the samples in Piedmontese cattle, although it was located at the beginning of BTA2, closest to the myostatin $(M S T N)$ locus. Karimi [12] identified the most common pattern in indicine breeds on BTA21, with a value exceeding $93 \%$ of individuals.

The high LD levels found in the majority of SNPs within the $\mathrm{ROH}$ islands are not surprisingly since selection in cattle has possibly acted to maintain conserved $\mathrm{ROH}$ regions originated from IBD segments. These segments are likely to have experienced fewer recombination events and they are expected to display high levels of LD. Besides, a study on human populations has shown a correlation between extensive LD, locally low recombination rates and high incidence of $\mathrm{ROH}$ [2].

Several genomic regions with significant SNPs $(-\log 10(\mathrm{p})>4)$ based on the integrated Haplotype Score

Table 2 Descriptive statistics of the pedigree-based inbreeding coefficient $\left(F_{P E D}\right)$ and genomic inbreeding coefficients based on runs of homozygosity $\left(F_{\mathrm{ROH}}\right)$ for different lenghts $\left(\mathrm{F}_{\mathrm{ROH} 1-2} \mathrm{Mb}, \mathrm{F}_{\mathrm{ROH} 2-4 \mathrm{Mb}}, \mathrm{F}_{\mathrm{ROH} 4-8 \mathrm{Mb}}, \mathrm{F}_{\mathrm{ROH} 8-16 \mathrm{Mb}}\right.$, and $\left.\mathrm{F}_{\mathrm{ROH}>16 \mathrm{Mb}}\right)$ for genotyped animals $(n)$

\begin{tabular}{lllllll}
\hline Inbreeding coefficient & Mean & Median & Minimum & Maximum & Coefficient of Variation (\%) & $n$ \\
\hline$F_{\text {PED }}$ & 0.019 & 0.004 & 0.000 & 0.327 & 3.38 & 2758 \\
$F_{\mathrm{ROH} 1-2 \mathrm{Mb}}$ & 0.017 & 0.017 & 0.006 & 0.037 & 20.70 & 2758 \\
$\mathrm{~F}_{\mathrm{ROH} 2-4 \mathrm{Mb}}$ & 0.013 & 0.013 & 0.001 & 0.039 & 35.30 & 2757 \\
$\mathrm{~F}_{\mathrm{ROH} 4-8 \mathrm{Mb}}$ & 0.013 & 0.012 & 0.001 & 0.063 & 55.63 & 2740 \\
$\mathrm{~F}_{\mathrm{ROH} 8-16 \mathrm{Mb}}$ & 0.014 & 0.012 & 0.003 & 0.082 & 73.04 & 2422 \\
$\mathrm{~F}_{\mathrm{ROH}>16 \mathrm{Mb}}$ & 0.023 & 0.016 & 0.006 & 0.201 & 97.75 & 1533 \\
\hline
\end{tabular}



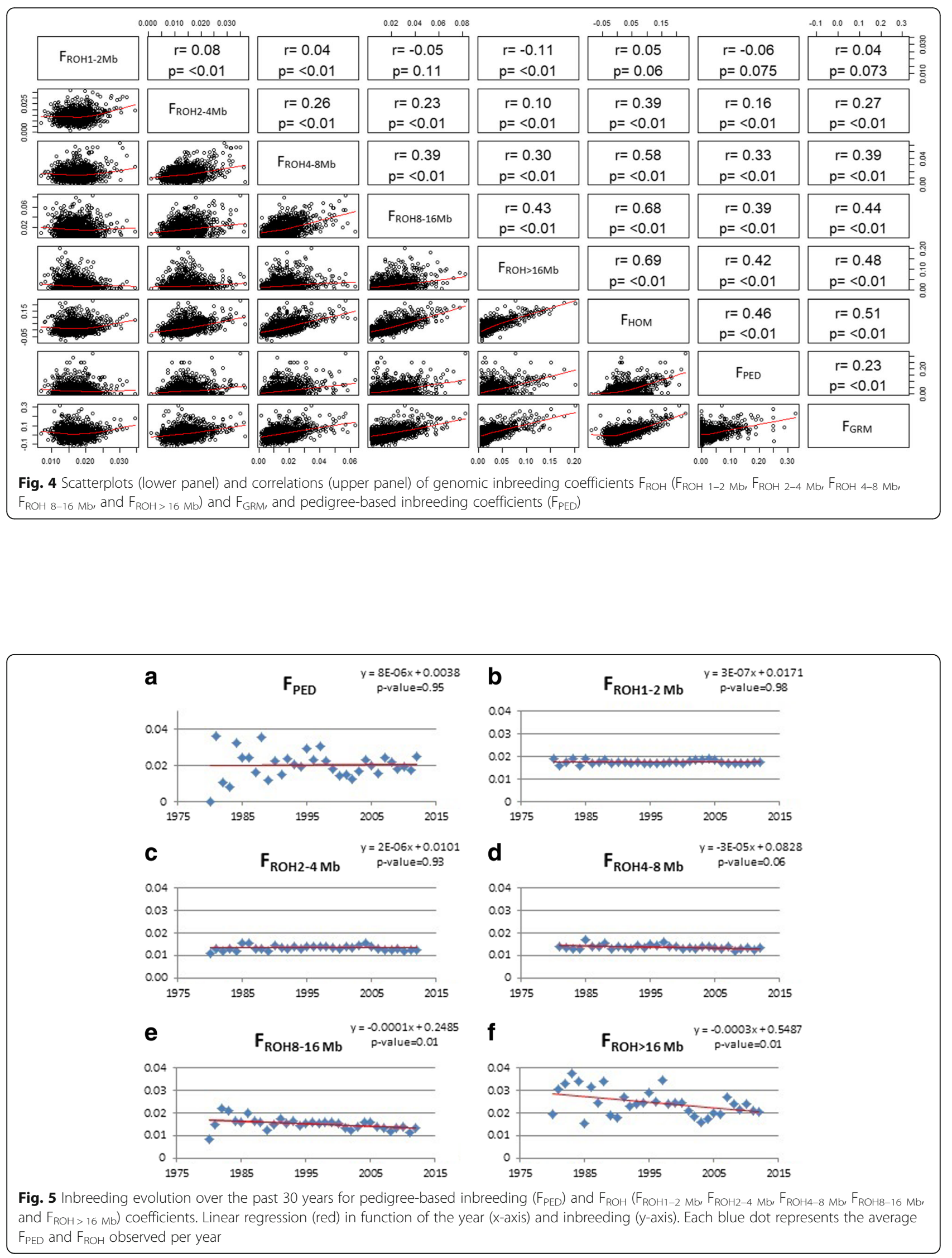
(iHS) were identified for the Gyr cattle by Utsunomiya et al. [35], using a subset of Gyr animals comprised in this study. Of the significant SNPs, seven of them were located within $\mathrm{ROH}$ islands described here on BTA2, BTA6, and BTA10 (Additional file 4).

When analyzing genomic positions of the identified $\mathrm{ROH}$ islands, the results pointed out by Szmatoła et al. [31] directly overlaps with some of the islands found in our study, with similar regions identified on BTA2 for Holstein, Polish Red and Limousin breeds, on BTA6 for Polish Red, Limousin and Simmental breeds, and on BTA14 for the Simmental cattle (Additional file 4). The Simmental breed also showed a ROH island on BTA6 located closely to the one described in this study for the Gyr cattle (70,117,799:81,603,050 bp). Karimi [12] and Sölkner et al. [36] study on Brahman, Gyr and Nellore cattle also identified $\mathrm{ROH}$ islands in some chromosomes as those described in this study. Although the islands on BTA10 and BTA12 were not found to be located at the same genomic region as in our study, the described island on BTA10 was found closest to ours. $\mathrm{ROH}$ islands identified on BTA6 were also described in Italian Holstein cattle [37], dairy and beef breeds [14], and in Tyrol Grey cattle [33], but none of them overlapped with those previously described for the Gyr cattle in this study. It is worth to highlight that BTA6 is well documented to harbor genes that affect milk production traits [38-41], thus, a high autozygosity in chromosomal regions may be an indicator of signatures of selection for dairy traits. Further, $\mathrm{ROH}$ islands were found overlapping in cattle breeds selected for different purposes, suggesting that selection pressure can also be undergoing on traits other than those specific to dairy or beef traits.

The GO analyses showed several enriched terms for the $\mathrm{ROH}$ gene list. A total of 10 genes were identified related to cell differentiation biological process (GO:0030154), in which we highlight the TRAPPC9 (trafficking protein particle complex 9) gene on BTA14. Interestingly, this gene was found to have significant effects on mastitis-related traits in Chinese Holstein herds [42]. Polymorphisms in TRAPPC9 gene has been associated with milk production traits in Holstein cattle [43]. Jiang et al. [44] observed a higher TRAPPC9 mRNA expression level in the mammary gland of lactating cows than in the other tissues, such as heart, liver, lung, kidney, ovary, uterus, and muscle.

Seven genes identified in $\mathrm{ROH}$ islands were related to positive regulation of cell migration (GO:0030335) biological process. Of these, the IRS2 (insulin receptor substrate 2), ATP8A1 (ATPase phospholipid transporting 8A1), GABRG1 (gamma-aminobutyric acid type A receptor gammal subunit), and GABRAG2 (gammaaminobutyric acid type A receptor gamma2 subunit) genes have been previously associated with dairy traits. The IRS2 gene on BTA12 encodes the insulin receptor substrate 2, a cytoplasmic signaling molecule that mediates effects of insulin, insulin-like growth factor 1 and other cytokines (provided by RefSeq, Jul 2008). Insulin infusion has been shown to increase milk and protein yields, and reduce milk fat content and yield in lactating goats. It also decreased net uptake of C10:0, C14:0, C16:0, trans-C16:1 and >C18:0 fatty acids, and increased mammary blood flow by $42 \%$ [45]. The ATP8A1, GABRG1, and GABRAG2 genes on BTA6 laid within the region with highest iHS score as reported by Hayes et al. [46] in Norwegian Red cattle, a breed which has been intensely selected for milk production.

The nuclear stress granule (GO:0097165) cellular component was substantially enriched $(p \leq 0.05)$, which contains the HSF1 (heat shock transcription factor 1) gene on BTA14. This gene encodes a heat-shock transcription factor, and its transcription is rapidly induced after heat stress (provided by RefSeq, Jul 2008). Heat shock transcription factors and heat shock proteins (HSP) play a crucial role in environmental stress adaptation and thermal balance since it allows cells to adapt to gradual environmental changes, being an immunoregulatory agent upon controlling the balance between survival and an effective immune system in order to adjust to stress [47]. Kumar et al. [48] observed a higher abundance of HSP family genes during summer and winter compared to the mid-spring season in Bos indicus cattle and Murrah buffaloes, and the magnitude of increase was higher during summer as compared to winter. Among their findings, a significantly $(p \leq 0.001)$ higher HSF1 mRNA expression during the summer as compared to the mid-spring season was also observed. These findings are consistent with the zebu cattle adaptation traits, in which we highlight its greater ability to tolerate poor feed and inconsistent climate. Li et al. [49] identified polymorphisms in HSF1 gene associated with thermal tolerance in Holstein cattle. In addition to the HSF1 gene, other heat shock genes were found within a $\mathrm{ROH}$ island on BTA2, such as HSPD1 (heat shock protein family D (Hsp60) member 1) and HSPE1 (heat shock protein family E (Hsp10) member 1).

We also encountered a number of genes within $\mathrm{ROH}$ islands that have been reported to have a prominent importance in milk-related traits on BTA2 (STAT1 and INSIG2 genes) [50, 51], BTA10 (ANG gene) [52] and BTA14 (EEF1D, CRH, DGAT1, and CYP11B1 genes) [53-60]. In addition, mammary gland developmentrelated genes were also described on BTA6 (IGFBP7 gene) $[61,62]$ and BTA14 (EEF1D gene) [44, 63].

A total of seven KEGG pathways were identified as being enriched $(p \leq 0.05)$ and the GABAergic synapse (bta04727) was the most significant $(p<0.001)$ KEGG pathway found (Additional file 3). Gamma-aminobutyric acid (GABA) is an inhibitory neurotransmitter in the 
mammalian central nervous system and the GABAergic synapse pathway has been associated with animal feed intake and weight gain [64]. Among the others KEGG pathways identified, the ones related to environmental information processing were highlighted, such as neuroactive ligand-receptor interaction (bta04080), PI3K-Akt signaling pathway (bta04151), and AMPK signaling pathway (bta04152) with 11, 10, and 5 genes identified within $\mathrm{ROH}$ islands, respectively. PI3K-Akt signaling pathway regulates key cellular functions such as transcription, translation, growth, proliferation, and survival. This pathway has been associated with prolactin signaling, mammary development, and involution in HolsteinFriesian and Jersey breeds [65]. AMPK signaling pathway acts as a sensor of cellular energy status leading to a concomitant inhibition of energy-consuming biosynthetic pathways and activation of ATP-producing catabolic pathways.

Instead of being randomly distributed across the genomes, $\mathrm{ROH}$ patterns were seen clustering in specific genomic regions among individuals. These regions were screened for genes under selection and several $\mathrm{ROH}$ islands harboring dairy-related genes have been identified, suggesting a directional selection for milk and mastitisrelated traits, mammary gland development, and environmental adaptation traits. Surprisingly, BTA14 has shown an enrichment of genes affecting traits of interest for dairy breeders. BTA2 and BTA6 also have shown ROH islands previously described in the literature, and these chromosomes along with BTA10 also revealed signatures of selection previously identified for the Gyr breed [33]. These findings suggest that these chromosomes are likely to contain traces of selection since $\mathrm{ROH}$ patterns are not expected to be randomly distributed over the genomes [13]. Also, they evidenced that $\mathrm{ROH}$ can reveal signatures of selection since $\mathrm{ROH}$ islands described in here corroborated with footprints of recent positive selection previously described for the Gyr cattle [35].

\section{Inbreeding coefficients}

The higher the $\mathrm{CV}$ was, the greater the differences between the mean and median were for each $\mathrm{F}_{\mathrm{ROH}}$ length (Table 2). Thus, given the dissimilarity among the $\mathrm{CV}$, it is assumed that the mean should not be used as the best measurement of central tendency, indicating that the median should be applied instead for $\mathrm{F}_{\mathrm{PED}}$ and $\mathrm{F}_{\mathrm{ROH}} \mathrm{co}-$ efficients. The average $F_{P E D}$ and $F_{R O H}$ were low for the Gyr cattle, and the $F_{P E D}$ estimate was lower than those reported by Reis Filho et al. [24] and Santana Junior et al. [32] for Brazilian Gyr cattle, with values of 2.82 and $1.92 \%$, respectively.

The age of inbreeding can be defined as the distance with the common ancestor and there is an approximate correlation with the length of the $\mathrm{ROH}[4,66]$. Under the assumption that $1 \mathrm{cM}$ equals to $1 \mathrm{Mb}$ [4], calculated $\mathrm{F}_{\mathrm{ROH}}$ are expected to correspond to the reference ancestral population dating $50\left(\mathrm{~F}_{\mathrm{ROH} 1-2 \mathrm{Mb}}\right), 20\left(\mathrm{~F}_{\mathrm{ROH} 2-4 \mathrm{Mb}}\right)$, 12.5 (FROH4-8 Mb), $6\left(\mathrm{~F}_{\mathrm{ROH} 8-16 \mathrm{Mb}}\right)$, and $3\left(\mathrm{~F}_{\mathrm{ROH}}>16 \mathrm{Mb}\right)$ generations ago. Zavarez et al. [11] observed that incomplete pedigree fails to capture remote inbreeding and estimates based on $F_{P E D}$ are only comparable with $F_{R O H}$ calculated over large $\mathrm{ROH}$. Thus, given the average pedigree depth of three generations, $\mathrm{F}_{\mathrm{PED}}$ estimate should be comparable with $\mathrm{F}_{\mathrm{ROH}}>16 \mathrm{Mb}$. The variation between these two estimates can be attributed to the fact that $F_{P E D}$ assumes that the entire genome does not undergo selection [20] and recombination events, therefore, it does not take into account potential bias from these events [67]. In addition, it should be underlined that pedigree relatedness is estimated from statistical expectations of the probable IBD genomic proportion, whereas genotype-based estimates show the actual relatedness among individuals [17] and can provide greater accuracy on relatedness.

The increasing correlation between $\mathrm{F}_{\mathrm{PED}}-\mathrm{F}_{\mathrm{ROH}}$ with $\mathrm{ROH}$ length may be explained by considering that $\mathrm{ROH}$ reflect both past and recent relatedness and that $F_{P E D}$ estimates are based on pedigree records which may not extend back many generations $[9,14]$. When longer $\mathrm{ROH}$ reflecting recent relatedness are considered to calculate $\mathrm{F}_{\mathrm{ROH}}$, the $\mathrm{F}_{\mathrm{PED}}-\mathrm{F}_{\mathrm{ROH}}$ correlation tends to be higher $[14,68]$. Several authors have described a high $F_{P E D}-F_{R O H}$ correlation when a deeper number of described generations are available in the pedigree $[6,8,9,14,29]$, suggesting that the correlation between these parameters increases with pedigree deep. Ferenčaković et al. $[8,9]$ observed $F_{P E D}-F_{R O H}$ correlations values ranging from 0.61 to 0.67 and 0.50 to 0.72 , respectively, for pedigrees with more than five generations. Purfield et al. [6] used a complete generation equivalents higher than six and obtained $\mathrm{F}_{\mathrm{PED}}-\mathrm{F}_{\mathrm{ROH}}$ correlations of 0.73 for $\mathrm{ROH}>10 \mathrm{Mb}$ and 0.71 for $\mathrm{ROH}>1 \mathrm{Mb}$, both with the reduced panel. Marras et al. [14] observed high $\mathrm{F}_{\mathrm{PED}}-\mathrm{F}_{\mathrm{ROH}}$ correlations using pedigree with four, seven and ten generations, with values ranging from 0.56 to 0.74 . Gurgul et al. [29] also reported the highest $\mathrm{F}_{\mathrm{PED}}-\mathrm{F}_{\mathrm{ROH}}$ correlation for animals with seven complete generations of pedigree data, with an average value of 0.45 . In the present study, a small number of generations were available to estimate $\mathrm{F}_{\mathrm{PED}}$, which may have introduced biased $\mathrm{F}_{\mathrm{PED}}$ values as the pedigree was not able to cover ancient relatedness.

The slight correlation between $\mathrm{F}_{\mathrm{PED}}-\mathrm{F}_{\mathrm{GRM}}$ concurs with the results obtained by Pryce et al. [69]. VanRaden et al. [70] reported higher correlations for Holstein (0.59), Jersey (0.68), and Brown Swiss (0.61) animals. Hayes and Goddard [71] also obtained higher correlations for Australian Angus bulls (0.69). Lower correlations between these estimates were reported by Marras et al. [14], 
Gurgul et al. [29], and Zhang et al. [72]. In the dairy industry, genomic inbreeding coefficients of genotyped animals are commonly calculated from $\mathrm{F}_{\mathrm{GRM}}$ [73]. Two out of three reasons hypothesized by Pryce et al. [69] might explain the poor correlation found out in our study: (i) $F_{G R M}$ is strongly dependent on allele frequencies, and population with divergent allele frequencies can lead to misleading IBD results; and (ii) pedigree completeness.

It is well addressed in the literature that incomplete pedigree information reduces estimates of inbreeding and leads to underestimated values [74, 75], as well as missing or incorrect pedigree information. Hence, accurate estimates of $F_{P E D}$ depend on a well-structured pedigree dataset. When analyzing the Gyr pedigree structure, it was observed that $72.96 \%$ of the animals available in the pedigree dataset had both known sire and dam information, and $3.52 \%$ had only known sire and $1.16 \%$ known dam information. On the basis of the results, $F_{\text {PED }}$ estimate might have been underestimated as well as its correlations with other inbreeding measurements due in part to the poor pedigree depth and pedigree incompleteness.

Several studies also have found a low to moderate $\mathrm{F}_{\mathrm{GRM}}-\mathrm{F}_{\mathrm{ROH}}$ correlation for dairy breeds $[14,28]$. In Holstein cattle, moderate to high correlations were described by Bjelland et al. [73] (0.81). Pryce et al. [69] observed a correlation of 0.62 in Holstein and Jersey populations, and Zavarez et al. [11] correlations ranging from 0.41 to 0.74 in Nellore cattle based on $\mathrm{ROH}$ of different minimum lengths. Further, the moderate to high correlations between $\mathrm{F}_{\mathrm{ROH}}$ and the two other estimates of genomic inbreeding $\left(\mathrm{F}_{\mathrm{GRM}}\right.$ and $\left.\mathrm{F}_{\mathrm{HOM}}\right)$ suggest that the proportion of the genome in $\mathrm{ROH}$ can be an accurate estimator of the IBD genomic proportion.

The inbreeding evolution illustration (Fig. 5) stress out a significant $(p<0.01)$ decline in $\mathrm{F}_{\mathrm{ROH}}>8-16 \mathrm{Mb}$ and $\mathrm{F}_{\mathrm{ROH}}>16 \mathrm{Mb}$, and it is worth to highlight that these coefficients reflect an inbreeding up to six and just three generations ago, respectively. The $\mathrm{F}_{\mathrm{ROH}>8-16 \mathrm{Mb}}$ and $\mathrm{F}_{\mathrm{ROH}}>16 \mathrm{Mb}$ coefficients reduction since the 80's happen together with the creation of the Brazilian Dairy Gyr Breeding Program (PNMGL) and the implementation of the Gyr progeny testing, both in 1985. Probably, these facts suggest that different proven sires from divergent lines started to be incorporated into the population, and previously closed herds started to make use of these genetically evaluated sires in their breeding programs. Mating between herds increased after 2002, a fact that may have strongly contributed to reducing the average inbreeding by increasing the genetic exchange [32]. Additionally, Santana Junior et al. [32] reported that the degree of nonrandom mating was close to zero at the end of the last decade, indicating that better mating decisions were taken by the breeders to avoid mating between relatives, changing the mating policy and decreasing the genomic inbreeding level in these populations over time.

These findings reinforce the importance of effective breeding programs for maintaining genetic diversity and suitable inbreeding levels, contributing to a better understanding of the population structure and providing the basis to overcome challenges. Given the Gyr breed growth background, in which a small number of founder animals was imported to Brazil to disseminate the breed, information regarding genetic diversity within the Gyr cattle is therefore essential for genetic improvement and conservation programs.

\section{Conclusions}

Despite the reduced genetic basis and the limited number of animals imported to form the first Gyr dairy lines, the autozygotic proportion of the genome was considerably low in this population. Hence, maintaining a low autozygosity is crucial in cattle breeding populations, avoiding inbreeding depression [76] and reduced response in breeding programs [77]. Several common $\mathrm{ROH}$ islands have been found in the Gyr genome, suggesting that $\mathrm{ROH}$ might be used to identify genomic regions under selection signatures [78, 79]. Common islands on BTA2 and BTA14 are supposed to be a sign of strong selection for dairy and environmental adaptation traits as several genes associated with them were identified. Low correlations between $\mathrm{F}_{\mathrm{PED}-} \mathrm{F}_{\mathrm{ROH}}$ may be partly due to the relatively shallow depth of the pedigree, indicating that $\mathrm{F}_{\mathrm{PED}}$ is not the most suitable method to capture ancient inbreeding. The existence of moderate to high correlations between $\mathrm{F}_{\mathrm{ROH}}$ and other genomic inbreeding measures suggests that the levels of autozygosity derived from $\mathrm{ROH}$ can be used as an accurate estimator of individual inbreeding levels $[6,8,29,73]$. In addition, when analyzing the inbreeding evolution for the past 30 years, it can be seen a clear decay in $F_{\mathrm{ROH}}$ for segments higher than $4 \mathrm{Mb}$, reinforcing the importance of effective breeding programs and mating management. Our findings contribute to the understanding of the inbreeding effects when assessing genome-wide autozygosity, and how selection can shape the distribution of $\mathrm{ROH}$ islands in the cattle genome. Hence, this approach may contribute to comprehend the evolutionary process of the Gyr breed, i.e. selection and domestication process $[80,81]$, and provide the basis to overcome future challenges.

\section{Methods}

\section{Animals and genotyping}

The animals used in this study comprise the progeny test program from the National Program for Improvement of Dairy Gir (PNMGL), headed by Embrapa Dairy Cattle 
(Juiz de Fora, Minas Gerais, Brazil) in cooperation with the Brazilian Association of Dairy Gyr Breeders (ABCGIL) and the Brazilian Association of Zebu Breeders (ABCZ). The objective of the program is to promote the genetic improvement of the Gyr dairy cattle, through the identification and selection of genetically superior bulls for fat, protein and total solids in milk, as well as traits associated with animal conformation and management.

A total of 19 dams and 563 sires born between 1964 and 2013 were genotyped with the BovineHD BeadChip (Illumina Inc., San Diego, CA, USA), containing 777,962 markers; 1664 dams with the BovineSNP50 BeadChip (Illumina Inc., San Diego, CA, USA), that contains 54,609 SNP; and 662 dams with the GGP-LD Indicus BeadChip (GeneSeek ${ }^{\circ}$ Genomic Profiler Indicus $30 \mathrm{~K}$ ), that contains 27,533 markers.

Imputation was implemented using the FIMPUTE 2.2 software [82], and lower density panels were imputed to the HD level. Imputation accuracy was 0.99, in accordance with the results presented by Boisin et al. [83] using the same population (0.98). SNPs unsigned to any chromosome and mapped to sexual chromosomes were removed from the dataset. The animals genotyped with the BovineHD BeadChip (Illumina Inc., San Diego, CA, USA) were used as reference population for imputation. The missing genotypes were imputed in the reference population and all the markers were retained. Prior imputation, samples were edited for call rate $(<90 \%)$. After editing the reference and imputed genotypes, a total of 2908 animals and 735,236 SNPs were retained for the analyses.

\section{Runs of homozygosity}

$\mathrm{ROH}$ were identified in every individual using PLINK v1.90 [84]. The PLINK software uses a sliding window of a specified length or number of homozygous SNPs to scan along each individual's genotype at each SNP marker position to detect homozygous segments [4]. The parameters and thresholds applied to define a $\mathrm{ROH}$ were (i) a sliding window of 50 SNPs across the genome; (ii) the proportion of homozygous overlapping windows was 0.05; (iii) the minimum number of consecutive SNPs included in a $\mathrm{ROH}$ was 100; (iv) the minimum length of a $\mathrm{ROH}$ was set to $1 \mathrm{Mb}$; (v) the maximum gap between consecutive homozygous SNPs was $500 \mathrm{~kb}$; (vi) a density of one SNP per $50 \mathrm{~kb}$; and (vii) a maximum of five SNPs with missing genotypes and up to one heterozygous genotype were allowed in a $\mathrm{ROH}$. The $\mathrm{ROH}$ were defined by a minimum of $1 \mathrm{Mb}$ in length to avoid short and common $\mathrm{ROH}$ that occur throughout the genome due to LD [6]. $\mathrm{ROH}$ were classified into five length classes: $1-2,2-4,4-8,8-16$, and $>16 \mathrm{Mb}$, identified as $\mathrm{ROH}_{1-2 \mathrm{Mb}}, \mathrm{ROH}_{2-4 \mathrm{Mb}}, \mathrm{ROH}_{4-8 \mathrm{Mb}}, \mathrm{ROH}_{8-16 \mathrm{Mb}}$, and $\mathrm{ROH}_{>16 \mathrm{Mb}}$, respectively.

\section{Pedigree and genomic inbreeding coefficients}

Four types of inbreeding coefficients $\left(\mathrm{F}_{\mathrm{PED}}, \mathrm{F}_{\mathrm{ROH}}, \mathrm{F}_{\mathrm{GRM}}\right.$, and $\mathrm{F}_{\mathrm{HOM}}$ ) were taken into account. Pedigree-based inbreeding coefficients $\left(\mathrm{F}_{\mathrm{PED}}\right)$ were estimated for all animals using pedigree records from a dataset containing 101,351 animals born between 1946 and 2015. The pedigree data was provided by Embrapa Dairy Cattle (Juiz de Fora, Minas Gerais, Brazil). The average pedigree depth was approximately three generations ranging from 0 to 7.85 . The $F_{P E D}$ was estimated through the software INBUPGF90 [85]. Genomic inbreeding coefficients based on $\mathrm{ROH}\left(\mathrm{F}_{\mathrm{ROH}}\right)$ were estimated for each animal according to McQuillan et al. [86]:

$$
F_{R O H}=\frac{\sum_{j=1}^{n} L_{R O H j}}{L_{\text {total }}}
$$

where $\mathrm{L}_{\mathrm{ROHj}}$ is the length of $\mathrm{ROH}_{\mathrm{j}}$, and $\mathrm{L}_{\text {total }}$ is the total size of the autosomes covered by markers. $\mathrm{L}_{\text {total }}$ was taken to be 2,510,605,962 bp, based on the consensus map. For each animal $\mathrm{F}_{\mathrm{ROH}}\left(\mathrm{F}_{\mathrm{ROH} 1-2 \mathrm{Mb}}, \mathrm{F}_{\mathrm{ROH} 2-4 \mathrm{Mb}}\right.$, $\mathrm{F}_{\mathrm{ROH} 4-8 \mathrm{Mb}}, \mathrm{F}_{\mathrm{ROH} 8-16 \mathrm{Mb}}$, and $\mathrm{F}_{\mathrm{ROH}>16 \mathrm{Mb}}$ ) was calculated based on $\mathrm{ROH}$ distribution of five minimum different lengths $\left(\mathrm{ROH}_{\mathrm{j}}\right): 1-2,2-4,4-8,8-16$, and $>16 \mathrm{Mb}$, respectively. A second measure of genomic inbreeding was calculated from a Genomic relationship matrix (G) and was denoted as $\mathrm{F}_{\mathrm{GRM}}$. The $\mathrm{G}$ matrix was calculated according to the method described by VanRaden et al. [70] using the following formula:

$$
G=\frac{Z Z^{\prime}}{2 \sum_{i=1}^{n} P_{i}\left(1-P_{i}\right)}
$$

where $Z$ is a genotype matrix that contains the $0-2 p$ values for homozygotes, $1-2 p$ for heterozygotes, and $2-2 p$ for opposite homozygotes, where $P_{i}$ is the reference allele frequency at locus $i$ th. The diagonal elements of the matrix $G$ represent the relationship of the animal with itself, thus, it was used to assess the genomic inbreeding coefficient. Inbreeding based on the observed versus expected number of homozygous genotypes $\left(\mathrm{F}_{\mathrm{HOM}}\right)$ was calculated in PLINK v1.90 [84] by computing observed and expected autosomal homozygous genotypes counts for each sample, as follows:

$$
F_{H O M}=\frac{\text { Observed hom.count-Expected count }}{\text { Total observations-Expected count }}
$$

Spearmann's correlation coefficients between the inbreeding measures were estimated. 


\section{Gene prospection in shared $\mathrm{ROH}$ regions}

The homozygous segments shared by more than $50 \%$ of the samples were chosen as an indication of possible $\mathrm{ROH}$ islands throughout the genome. The -homozyggroup function implemented in PLINK v1.90 [84] was used to assess $\mathrm{ROH}$ islands shared among individuals. The Map Viewer of the bovine genome UMD3.1.1 was used for identification of genes in $\mathrm{ROH}$ regions, available at "National Center for Biotechnology Information" (NCBI Map Viewer - https://www.ncbi.nlm.nih.gov/ mapview/). Database for Annotation, Visualization, and Integrated Discovery (DAVID) v6.8 tool $[26,27]$ was used to identify significant $(p \leq 0.05)$ Gene Ontology (GO) terms and KEGG (Kyoto Encyclopedia of Genes and Genomes) pathways using the list of genes from $\mathrm{ROH}$ islands and the Bos taurus annotation file as background.

\section{Additional files}

\section{Additional file 1: Gene content inside runs of homozygosity} overlapping regions (ROH Islands). (DOCX $27 \mathrm{~kb}$ )

Additional file 2: Mean linkage disequilibrium (LD) estimated considering a physical distance lower than $100 \mathrm{~kb}$ between markers for each Bos taurus autosome and within each runs of homozygosity island. (DOCX $17 \mathrm{~kb})$

Additional file 3: Gene Ontology (GO) terms and KEGG pathways enriched $(p<0.05)$ based on runs of homozygosity islands. (DOCX $30 \mathrm{~kb}$ )

Additional file 4: Runs of homozygosity islands and signatures of selection located within or closely to those islands observed in the present study. (DOCX $19 \mathrm{~kb}$ )

\section{Abbreviations \\ ABCGIL: Brazilian Association of Dairy Gyr Breeders; ABCZ: Brazilian Association of Zebu Breeders; CV: Coefficient of variation; DAVID: Database for Annotation, Visualization, and Integrated Discovery; FGRM: Genomic relationship matrix-based estimates of inbreeding; $\mathrm{F}_{\mathrm{HOM}}$ : Inbreeding estimate based on observed and expected autosomal homozygous genotypes; $F_{P E D}$ : Pedigree-based estimates of inbreeding; $\mathrm{F}_{\mathrm{ROH}}$ : $\mathrm{ROH}$-based estimates of inbreeding; G: Genomic relationship matrix; GO: Gene Ontology; IBD: Identical by descent; IBS: Identical by state; KEGG: Kyoto Encyclopedia of Genes and Genomes; LD: Linkage disequilibrium; PNMGL: National Program for Improvement of Dairy Gir; ROH: Runs of homozygosity}

\section{Acknowledgements}

E.P received a scholarship from Coordination for the Improvement of Higher Education Personnel (CAPES) in cooperation with the Brazilian Agricultural Research Corporation (EMBRAPA). N.B.S. was supported by postdoctoral fellowship from CAPES. F.B, D.P.M and M.V.G.B.S held productivity research fellowships from The Brazilian National Council for Scientific and Technological Development (CNPQ).

\section{Funding}

Marcos V. G. B. Silva was supported by the Embrapa (Brazil) SEG 02.09.07.008.00.00 "Genomic Selection in Dairy Cattle in Brazil," CNPq PVE 407246/2013-4 "Genomic Selection in Dairy Gyr and Girolando Breeds," and FAPEMIG CVZ PPM 00606/16 "Identification of Signatures of Selection using Next Generation Sequencing Data" appropriated projects.

\section{Availability of data and materials}

The genomic information used in this study belongs to Brazilian Agricultural Research Corporation (Embrapa), so we do not have authorization to share the data.

\section{Authors' contributions}

EP, DPM, MAM, JCCP, MVGBS, and FB conceived and designed the experiment. $E P, R W$, and FB carried out the data analyses. EP, NBS, ALFL, RI, DPM, RW, MAM, JCCP, MVGBS, and FB interpreted the results and drafted the manuscript. NBS, DPM, ALFL, RI, MAM, JCCP, RW, and MVGBS helped to draft and revise the manuscript. All authors read and approved the final manuscript.

\section{Ethics approval and consent to participate}

The DNA was extracted from semen bought from an artificial insemination center and therefore no specific ethical approval is needed (Brazil law number 11794, from October 8th, 2008, Chapter 1, Art. 3, paragraph III). All the samples were obtained with the consent of the artificial insemination center to use for research.

\section{Consent for publication}

Not applicable.

\section{Competing interests}

The authors declare that they have no competing interests.

\section{Publisher's Note}

Springer Nature remains neutral with regard to jurisdictional claims in published maps and institutional affiliations.

\section{Author details}

${ }^{1}$ Faculdade de Ciências Agrárias e Veterinárias, Departamento de Zootecnia, UNESP Univ Estadual Paulista Júlio de Mesquita Filho, Jaboticabal 14884-900, Brazil. ${ }^{2}$ Faculdade de Ciências Agrárias e Veterinárias, Departamento de Ciências Exatas, UNESP Univ Estadual Paulista Júlio de Mesquita Filho, Jaboticabal 14884-900, Brazil. ${ }^{3}$ Conselho Nacional de Desenvolvimento Científico e Tecnológico (CNPQ), Lago Sul 71605-001, Brazil. ${ }^{4}$ Centro de Ciências Agrárias, Departamento de Zootecnia e Desenvolvimento Rural, Universidade Federal de Santa Catarina, Florianópolis 88034-000, Brazil. ${ }^{5}$ Embrapa Gado de Leite, Juiz de Fora 36038-330, Brazil. ${ }^{6}$ Faculdade de Zootecnia e Engenharia de Alimentos, Universidade de São Paulo, Pirassununga 13635-900, Brazil. ${ }^{7}$ Beef Improvement Opportunities, Elora, ON NOB 1S0, Canada. ${ }^{8}$ University of Guelph, Centre for Genetic Improvement of Livestock, ABScBG, Guelph N1G 2W1, Canada.

Received: 14 February 2017 Accepted: 4 December 2017

Published online: 09 January 2018

\section{References}

1. Broman KW, Weber JL. Long homozygous chromosomal segments in reference families from the centre d'Etude du polymorphisme humain. Am J Hum Genet. 1999;65:1493-500.

2. Gibson J, Morton NE, Collins A. Extended tracts of homozygosity in outbred human populations. Hum Mol Genet. 2006;15:789-95.

3. Falconer DS, Mackay TFC. Introduction to quantitative genetics. Essex: Pearson; 1996.

4. Howrigan DP, Simonson MA, Keller MC. Detecting autozygosity through runs of homozygosity: a comparison of three autozygosity detection algorithms. BMC Genomics. 2011;12:460.

5. Bosse M, Megens HJ, Madsen O, Paudel Y, Frantz LAF, Schook LB, et al. Regions of Homozygosity in the porcine genome: consequence of demography and the recombination landscape. PLoS Genet. 2012;8:e1003100.

6. Purfield DC, Berry DP, MCParland S, Bradley DG. Runs of homozygosity and population history in cattle. BMC Genet. 2012:13:70.

7. Herrero-Medrano JM, Megens H-J, Groenen MAM, Ramis G, Bosse M, Pérez-Enciso M, et al. Conservation genomic analysis of domestic and wild pig populations from the Iberian peninsula. BMC Genet. 2013;14:106.

8. Ferenčaković M, Hamzic E, Gredler B, Curik I, Sölkner J. Runs of Homozygosity reveal genome-wide Autozygosity in the Austrian Fleckvieh cattle. Agric Conspec Sci. 2011;76:325-9.

9. Ferenčaković M, Hamzić E, Gredler B, Solberg TR, Klemetsdal G, Curik I, et al. Estimates of autozygosity derived from runs of homozygosity: empirical evidence from selected cattle populations. J Anim Breed Genet. 2013;130:286-93.

10. Kim ES, Cole JB, Huson H, Wiggans GR, Van Tassel CP, Crooker BA, et al. Effect of artificial selection on runs of homozygosity in U.S. Holstein cattle. PLoS One. 2013;8:e80813. 
11. Zavarez LB, Utsunomiya YT, Carmo AS, Neves HHR, Carvalheiro R, Ferencakovic M, et al. Assessment of autozygosity in Nellore cows (Bos Indicus) through high-density SNP genotypes. Front Genet. 2015;6:1-8.

12. Karimi S. Runs of Homozygosity Patterns in Taurine and Indicine Cattle Breeds (Master thesis). Vienna: BOKU - University of Natural Resources and Life Sciences; 2013. p. 53.

13. Zhang Q, Guldbrandtsen B, Bosse M, Lund MS, Sahana G. Runs of homozygosity and distribution of functional variants in the cattle genome. BMC Genomics. 2015;16:542.

14. Marras G, Gaspa G, Sorbolini S, Dimauro C, Ajmone-Marsan P, Valentini A, et al. Analysis of runs of homozygosity and their relationship with inbreeding in five cattle breeds farmed in Italy. Anim Genet. 2014;46:110-21.

15. Wright S. Coefficients of inbreeding and relationship. Am Nat. 1922;56:330-8.

16. Meuwissen THE, Hayes BJ, Goddard ME. Prediction of Total genetic value using genome-wide dense marker maps. Genetics. 2001;157:1819-29.

17. Visscher PM, Medland SE, Ferreira MAR, Morley Kl, Zhu G, Cornes BK, et al. Assumption-free estimation of heritability from genome-wide identity-bydescent sharing between full siblings. PLoS Genet. 2006:2:0316-25.

18. VanRaden PM. Efficient methods to compute genomic predictions. J Dairy Sci. 2008;91:4414-23.

19. Keller MC, Visscher PM, Goddard ME. Quantification of inbreeding due to distant ancestors and its detection using dense single nucleotide polymorphism data. Genetics. 2011;189:237-49.

20. Curik I, Sölkner J, Stipic N. Effects of models with finite loci, selection, dominance, epistasis and linkage on inbreeding coefficients based on pedigree and genotypic information. J Anim Breed Genet. 2002;119:101-15.

21. Santiago AA. O Zebu na Índia, no Brasil e no mundo. Instituto Campineiro de ensino agrícola: Campinas; 1986.

22. Queiroz SA, Lôbo RB. Genetic relationship, inbreeding and generation interval in registered Gir cattle in Brazil. J Anim Breed Genet. 1993;110:228-33.

23. Peripolli E, Munari DP, Silva MVGB, Lima ALF, Irgang R, Baldi F. Runs of homozygosity: current knowledge and applications in livestock. Anim Genet. 2016:48:255-71

24. Filho Reis JC, da Verneque Silva R, RDA T, Lopes PS, FSS R, FLB T. Inbreeding on productive and reproductive traits of dairy Gyr cattle. Rev Bras Zootec. 2015:44:174-9

25. Wang Y. Runs of Homozygosity Patterns in Taurine and Indicine Cattle Breeds (Master thesis). Vienna: BOKU-University of Natural Resources and Life Sciences; 2015. p. 37.

26. Huang DW, Sherman BT, Lempicki RA. Bioinformatics enrichment tools: paths toward the comprehensive functional analysis of large gene lists. Nucleic Acids Res. 2009;37:1-13.

27. Huang DW, Sherman BT, Lempicki RA. Systematic and integrative analysis of large gene lists using DAVID bioinformatics resources. Nat Protoc. 2009:4:44-57.

28. Mastrangelo S, Tolone M, Di Gerlando R, Fontanesi L, Sardina MT, Portolano B. Genomic inbreeding estimation in small populations: evaluation of runs of homozygosity in three local dairy cattle breeds. Animal. 2016:10:746-54.

29. Gurgul A, Szmatoła T, Topolski P, Jasielczuk I, Żukowski K, Bugno-Poniewierska M. The use of runs of homozygosity for estimation of recent inbreeding in Holstein cattle. J Appl Genet. 2016;57:527-30.

30. Kirin M, McQuillan R, Franklin CS, Campbell H, Mckeigue PM, Wilson JF. Genomic runs of homozygosity record population history and consanguinity. PLoS One. 2010;5:e13996.

31. Szmatoła T, Gurgul A, Ropka-molik K, Jasielczuk I, Tomasz Z, Bugno-poniewierska M. Characteristics of runs of homozygosity in selected cattle breeds maintained in Poland. Livest Sci. 2016;188:72-80.

32. Santana Junior ML, Pereira RJ, Bignardi AB, El Faro L, Tonhati $H$, Albuquerque LG. History, structure, and genetic diversity of Brazilian Gir cattle. Livest Sci. 2014;163:26-33.

33. Mészáros G, Boison AS, Pérez O’Brien AM, Ferenčaković M, Curik I, da Silva MV, et al. Genomic analysis for managing small and endangered populations : a case study in Tyrol Grey cattle. Front Genet. 2015;6:1-12.

34. Pemberton TJ, Absher D, Feldman MW, Myers RM, Rosenberg NA, Li JZ. Genomic patterns of homozygosity in worldwide human populations. Am J Hum Genet. 2012;91:275-92.

35. Utsunomiya YT, Pérez O'Brien AM, Sonstegard TS, Van Tassell CP, do Carmo AS, Mészáros $G$, et al. Detecting loci under recent positive selection in dairy and beef cattle by combining different genome-wide scan methods. PLoS One. 2013:8:e64280
36. Sölkner J, Karimi Z, Pérez O'Brien AM, Mészáros G, Eaglen S, Boison SA, et al. Extremely non-uniform : patterns of runs of Homozygosity in bovine populations. Vancouver: 10th World Congr. Genet. Appl. to Livest. Prod; 2014.

37. Gaspa G, Marras G, Sorbolini S, Marsan PA, Williams JL, Valentini A, et al. Genome-wide Homozygosity in Italian Holstein cattle using HD SNP panel. Vancouver: 10th World Congr. Genet. Appl. to Livest. Prod; 2014.

38. Cohen M, Reichenstein M, Everts-Van Der Wind A, Heon-Lee J, Shani M, Lewin HA, et al. Cloning and characterization of FAM13A1 - a gene near a milk protein QTL on BTA6: evidence for population-wide linkage disequilibrium in Israeli Holsteins. Genomics. 2004;84:374-83.

39. Cohen-Zinder M, Seroussi E, Larkin DM, Loor JJ, Everts-Van Der Wind A, Lee $\mathrm{JH}$, et al. Identification of a missense mutation in the bovine ABCG2 gene with a major effect on the QTL on chromosome 6 affecting milk yield and composition in Holstein cattle. Genome Res. 2005;15:936-44.

40. Schnabel RD, Kim J-J, Ashwell MS, Sonstegard TS, Van Tassell CP, Connor EE, et al. Fine-mapping milk production quantitative trait loci on BTA6: analysis of the bovine osteopontin gene. Proc Natl Acad Sci U S A. 2005:102:6896-901.

41. Schopen GCB, Visker MHPW, Koks PD, Mullaart E, van Arendonk JAM, Bovenhuis $\mathrm{H}$. Whole-genome association study for milk protein composition in dairy cattle. J Dairy Sci. 2011;94:3148-58.

42. Wang X, Ma P, Liu J, Zhang Q, Zhang Y, Ding X, et al. Genome-wide association study in Chinese Holstein cows reveal two candidate genes for somatic cell score as an indicator for mastitis susceptibility. BMC Genet. 2015;16:111.

43. Kai W, GuanBin L, TeMin H, ZhenFang W, BaoLi S, DeWu L. Associations of polymorphisms in TRAPPC9, DGAT1, ATP1A1and GHR genes with milk production traits in Holstein dairy cow in southern China. J S C Agric Univ. 2016;37:2016.

44. Jiang L, Liu X, Yang J, Wang H, Jiang J, Liu L, et al. Targeted resequencing of GWAS loci reveals novel genetic variants for milk production traits. BMC Genomics. 2014;15:1105.

45. Bequette BJ, Kyle CE, Crompton LA, Buchan V, Hanigan MD. Insulin regulates milk production and mammary gland and hind-leg amino acid fluxes and blood flow in lactating goats. J Dairy Sci Sci. 2001;84:241-55.

46. Hayes BJ, Lien S, Nilsen H, Olsen HG, Berg P, Maceachern S, et al. The origin of selection signatures on bovine chromosome 6. Anim Genet. 2008;39:105-11.

47. Morange M. HSFs in Development. In: Starke K, Gaestel M, editors. Molecular Chaperones in Health and Disease. Handbook of Experimental Pharmacology, vol 172. Berlin: Springer; 2006. https://doi.org/10.1007/3-540-29717-0_7.

48. Kumar A, Ashraf S, Goud TS, Grewal A, Singh SV, Yadav BR, et al. Expression profiling of major heat shock protein genes during different seasons in cattle (Bos Indicus) and buffalo (Bubalus Bubalis) under tropical climatic condition. J Therm Biol. 2015;51:55-64.

49. Li QL, Ju ZH, Huang JM, Li JB, Li RL, Hou MH, et al. Two novel SNPs in HSF1 gene are associated with thermal tolerance traits in Chinese Holstein cattle. DNA Cell Biol. 2011;30:247-54.

50. Cobanoglu O, Zaitoun I, Chang YM, Shook GE, Khatib H. Effects of the signal transducer and activator of transcription 1 (STAT1) gene on milk production traits in Holstein dairy cattle. J Dairy Sci. 2006:89:4433-7.

51. Rincon G, Islas-Trejo A, Castillo AR, Bauman DE, German BJ, Medrano JF. Polymorphisms in genes in the SREBP1 signalling pathway and SCD are associated with milk fatty acid composition in Holstein cattle. J Dairy Res. 2012;79:66-75

52. Li C, Cai W, Zhou C, Yin H, Zhang Z, Loor JJ, et al. RNA-Seq reveals 10 novel promising candidate genes affecting milk protein concentration in the Chinese Holstein population. Sci Rep. 2016;6:26813.

53. Jiang $L$, Liu J, Sun D, Ma P, Ding X, Yu Y, et al. Genome wide association studies for milk production traits in Chinese Holstein population. PLoS One. 2010:5:e13661.

54. Jansen $\mathrm{S}$, Aigner $\mathrm{B}$, Pausch $\mathrm{H}$, Wysocki M, Eck S, Benet-Pagès A, et al. Assessment of the genomic variation in a cattle population by re-sequencing of key animals at low to medium coverage. BMC Genomics. 2013;14:446.

55. Argov-Argaman N, Mida K, Cohen B-C, Visker M, Hettinga K. Milk fat content and DGAT1 genotype determine lipid composition of the milk fat globule membrane. PLoS One. 2013;8:e68707.

56. Grisart B, Farnir F, Karim L, Cambisano N, Kim J-J, Kvasz A, et al. Genetic and functional confirmation of the causality of the DGAT1 K232A quantitative trait nucleotide in affecting milk yield and composition. Proc Natl Acad SC U S A. 2004;101:2398-403. 
57. Thaller G, Kramer W, Winter A, Kaupe B, Erhardt G, Fries R. Effects of DGAT1 variants on milk production traits in Jersey cattle. J Anim Sci. 2003;81:1911-8.

58. Schennink A, Stoop WM, Visker MHPW, Heck JML, Bovenhuis H, Van Der Poel JJ, et al. DGAT1 underlies large genetic variation in milk-fat composition of dairy cows. Anim Genet. 2007;38:467-73.

59. Kaupe $B$, Brandt $H$, Prinzenberg EM, Erhardt $G$. Joint analysis of the influence of CYP11B1 and DGAT1 genetic variation on milk production, somatic cell score, conformation, reproduction, and productive lifespan in German Holstein cattle. J Anim Sci. 2007;85:11-21.

60. Maryam J, Babar ME, Nadeem A, Yaqub T, Hashmi AS. Identification of functional consequence of a novel selection signature in CYP1 1b1 gene for milk fat content in Bubalus Bubalis. Meta Gene. 2015;6:85-90.

61. Bartella V, De Marco P, Malaguarnera R, Belfiore A, Maggiolini M. New advances on the functional cross-talk between insulin-like growth factor-I and estrogen signaling in cancer. Cell Signal. 2012;24:1515-21.

62. Kleinberg DL, Barcellos-Hoff MH. The pivotal role of insulin-like growth factor I in normal mammary development. Endocrinol Metab Clin N Am. 2011;40:461-71.

63. Xie $Y$, Yang S, Cui X, Jiang L, Zhang S, Zhang Q, et al. Identification and expression pattern of two novel alternative splicing variants of EEF1D gene of dairy cattle. Gene. 2014;534:189-96.

64. Fan H, Wu Y, Zhou X, Xia J, Zhang W, Song Y, et al. Pathway-based genome-wide association studies for two meat production traits in Simmental cattle. Sci Rep. 2015;5:18389.

65. Raven L-A, Cocks BG, Goddard ME, Pryce JE, Hayes BJ. Genetic variants in mammary development, prolactin signalling and involution pathways explain considerable variation in bovine milk production and milk composition. Genet Sel Evol. 2014:46:29.

66. Curik I, Ferenčaković M, Sölkner J. Inbreeding and runs of homozygosity: a possible solution to an old problem. Livest Sci. 2014;166:26-34.

67. Carothers AD, Rudan I, Kolcic I, Polasek O, Hayward C, Wright AF, et al. Estimating human inbreeding coefficients: comparison of genealogical and marker heterozygosity approaches. Ann Hum Genet. 2006;70:666-76.

68. Saura M, Fernández A, Varona L, Fernández Al, de Cara MÁR, Barragán C, et al. Detecting inbreeding depression for reproductive traits in Iberian pigs using genome-wide data. Genet Sel Evol. 2015;47:1.

69. Pryce JE, Haile-Mariam M, Goddard ME, Hayes BJ. Identification of genomic regions associated with inbreeding depression in Holstein and Jersey dairy cattle. Genet Sel Evol. 2014;46:71.

70. VanRaden PM, Olson KM, Wiggans GR, Cole JB, Tooker ME. Genomic inbreeding and relationships among Holsteins, jerseys, and Brown Swiss. J Dairy Sci. 2011;94:5673-82.

71. Hayes BJ, Goddard ME. Technical note: prediction of breeding values using marker-derived relationship matrices. J Anim Sci. 2008:86:2089-92.

72. Zhang Q, Calus MPL, Guldbrandtsen B, Lund MS, Sahana G. Estimation of inbreeding using pedigree, 50k SNP chip genotypes and full sequence data in three cattle breeds. BMC Genet. 2015;16:88.

73. Bjelland DW, Weigel KA, Vukasinovic N, Nkrumah JD. Evaluation of inbreeding depression in Holstein cattle using whole-genome SNP markers and alternative measures of genomic inbreeding. J Dairy Sci. 2013;96:4697-706.

74. Lutaaya E, Misztal I, Bertrand JK, Mabry W. Inbreeding in populations with incomplete pedigrees. J Anim Breed Genet. 1999;116:475-80.

75. Cassell BG, Adamec V, Pearson RE. Effect of incomplete pedigrees on estimates of inbreeding and inbreeding depression for days to first service and summit milk yield in Holsteins and jerseys. J Dairy Sci. 2003;86:2967-76.

76. Miglior F, Szkotnicki B, Burnside EB. Analysis of levels of inbreeding and inbreeding depression in Jersey cattle. J Dairy Sci. 1992;75:1112-8.

77. Weigel KA. Controlling inbreeding in modern breeding programs. J Dairy Sci. 2001;84:E177-84.

78. Metzger J, Karwath M, Tonda R, Beltran S, Águeda L, Gut M, et al. Runs of homozygosity reveal signatures of positive selection for reproduction traits in breed and non-breed horses. BMC Genomics. 2015;16:764.

79. Purfield DC, McParland S, Wall E, Berry DP. The distribution of runs of homozygosity and selection signatures in six commercial meat sheep breeds. PLoS One. 2017;12:e0176780.

80. Machugh DE, Shriver MD, Loftus RT, Cunningham P, Bradley DG Domestication and Phylogeography of Taurine and zebu cattle. Genetics. 1997;146:1071-86.

81. Chan EKF, Nagaraj SH, Reverter A. The evolution of tropical adaptation: comparing taurine and zebu cattle. Anim Genet. 2010;41:467-77.
82. Sargolzaei M, Chesnais JP, Schenkel FS. A new approach for efficient genotype imputation using information from relatives. BMC Genomics. 2014;15:478.

83. Boison SA, Santos DJA, Utsunomiya AHT, Carvalheiro R, Neves HHR, O'Brien AMP, et al. Strategies for single nucleotide polymorphism (SNP) genotyping to enhance genotype imputation in Gyr (Bos Indicus) dairy cattle: comparison of commercially available SNP chips. J Dairy Sci. 2015;98:4969-89.

84. Purcell S, Neale B, Todd-Brown K, Thomas L, Ferreira MAR, Bender D, et al. PLINK: a tool set for whole-genome association and population-based linkage analyses. Am J Hum Genet. 2007;81:559-75.

85. Aguilar I, Misztal I. Technical note: recursive algorithm for inbreeding coefficients assuming nonzero inbreeding of unknown parents. J Dairy Sci. 2008;91:1669-72.

86. McQuillan R, Leutenegger AL, Abdel-Rahman R, Franklin CS, Pericic M, Barac-Lauc L, et al. Runs of Homozygosity in European populations. Am J Hum Genet. 2008:83:359-72.

\section{Submit your next manuscript to BioMed Central and we will help you at every step:}

- We accept pre-submission inquiries

- Our selector tool helps you to find the most relevant journal

- We provide round the clock customer support

- Convenient online submission

- Thorough peer review

- Inclusion in PubMed and all major indexing services

- Maximum visibility for your research

Submit your manuscript at www.biomedcentral.com/submit
Biomed Central 